\title{
Vztah mezi tělesnou zdatností a pohybovými dovednostmi u dětí středního školního věku
}

\section{The relationship between physical fitness and motor skills in middle childhood children}

\author{
Vlado Balaban, Damir Bešič \\ Fakulta tělesné kultury Univerzity Palackého v Olomouci
}

\begin{abstract}
Abstrakt
Hlavním cílem výzkumu bylo testování hrubých pohybových dovedností a tělesné zdatnosti u dètí středního školního věku pomocí testů TGMD-2 a FITNESSGRAM a posuzování vztahů mezi komponentami těchto dvou testů. Dílčím cílem byla analýza intersexuálních rozdílů. Výzkumný soubor tvořilo 51 chlapců a 49 dívek ve věku 9 až 11 let. Výsledky ukazují, že soubor chlapců má lepší výsledky ve většině subtestů tělesné zdatnosti a vyšší úroveň manipulačních hrubých pohybových dovedností. Dívky mají vyšší úroveň flexibility a lokomočních hrubých pohybových dovedností. Vztahy mezi subtesty TGDM-2 a FITNESSGRAM ukazuji na pozitivní korelace především mezi manipulačními dovednostmi a kardiovaskulární zdatností. U dětí středního školního věku je v rámci hodin tělesné výchovy důležité vybírat pohybové aktivity rozvijející kardiorespirační zdatnost. U dívek je zvláště důležité vybírat sportovní hry, ve kterých dominují manipulační hrubé pohybové dovednosti.
\end{abstract}

\begin{abstract}
The main aim of the research was to test the gross motor skills and physical fitness among children of middle childhood children with TGMD-2 and Fitnessgram tests and assessment of relations between components of these two tests. A partial goal was to analyze gender differences. The research sample consisted of 51 boys and 49 girls aged 9-11 years. The results indicate that the sample of boys have better results in most subtests of physical fitness and a higher level of manipulative gross motor skills. Girls have a higher level of flexibility and locomotor gross motor skills. Relations between subtests TGDM-2 and Fitnessgram showed mainly a positive correlation between manipulative skills and cardiovascular fitness. For middle childhood children is important to choose physical activities developing cardiorespiratory fitness during their physical education classes. For girls it is especially important to choose a sports, which including manipulative gross motor skills.
\end{abstract}

Klíčová slova: děti, zdravotně orientovaná zdatnost, pohybové dovednosti.

Keywords: children, health related fitness, movement skills.

\section{ÚVOD}

Pohyb a pohybová aktivita (PA) představují kritické aspekty života. Aby se člověk začlenil do pravidelné PA, je nutné, aby ovládal prvky hrubé motoriky. Hrubá motorika se skládá z hrubých pohybových dovedností: běhání, skákání, kopání, chytání a házení (Okely, Booth \& Patterson, 2001). Nízká úroveň osvojení hrubých pohybových dovedností u dětí představuje jeden z hlavních důvodů snížené motivace $\mathrm{k}$ začlenění do habituální PA se svými vrstevníky, což následně vede k poklesu tělesné zdatnosti (Kalaja, Jaakkola, Liukkonen, \& Watt, 2010; Lubans, Morgan, Cliff, Barnett, \& Okely, 2010; Okely et al., 2001). Tělesná zdatnost (TZ) zahrnuje následující 
komponenty důležité pro optimální tělesný rozvoj během dětství a dospívání: kardiorespirační zdatnost, svalovou vytrvalost a sílu, anaerobní vytrvalost, rychlost, obratnost a flexibilitu (Ortega et al., 2011; Rivilis et al., 2011). Optimální a dostatečná úroveň TZ u dětí mladšího školního věku představuje důležitý faktor prevence současných civilizačních nemocí, vznikajících z důvodu hypokinézy (Bunc, 2008). Naopak nízká úroveň TZ má negativní vliv na zdraví a pohodu („wellbeing“) (Morrow et al., 2013). Dovednosti zahrnují snahu k dosažení určitého cíle s maximalizující přesností pro dosažení tohoto cíle, s minimalizujícím psychofyzickým a energetickým výdejem i v minimálním čase (Schmidt \& Lee, 2014). Měkota a Cuberek (2007, s. 9) definují pohybové dovednosti jako „motorické učení a opakování získané pohotovosti (způsobilosti) k pohybové činnosti, k řešení pohybového úkolu a dosažení úspěšného výsledku“. Měkota a Cuberek (2007) dělí pohybové dovednosti podle rozsahu pohybu a zapojení svalových skupin na jemné a hrubé pohybové dovednosti. Jemné pohybové dovednosti představují především činnosti prstů ruky, u kterých je důležitá pohybová koordinace mezi okem a rukou, které jsou součástí každodenních pracovních a uměleckých činností (Měkota \& Cuberek, 2007). Hrubé pohybové dovednosti začleňují velké svalové skupiny, které umožňují chůzi, skoky, koordinaci a rovnováhu. Na této dovednosti se současně podílí svalové napětí a svalová síla. Děti s lépe vyvinutými hrubými pohybovými dovednostmi by se měly snadněji zapojit do většího objemu PA a být pohybově aktivnější, než děti s méně vyvinutými hrubými pohybovými dovednostmi (Williams et al., 2008). Během dětství a dospívání dochází $\mathrm{k}$ výrazným fyziologickým a psychologickým změnám $\mathrm{v}$ organizmu člověka, a proto je toto období označováno za klíčovou periodu v ontogenezi. Během toho období se buduje zdravý nebo nezdravý životní styl (Molnár \& Livingstone, 2000). Střední až vysoká úroveň ovladatelnosti hrubých pohybových dovedností potřebná pro úspěšnou účast $\mathrm{v}$ mnohých sportech a druzích PA může být vztažena $\mathrm{k}$ vyšší úrovni výkonnosti a zdravotně orientované zdatnosti (ZOZ). Na provádění hrubých pohybových dovedností se podílí dostatečně vysoká úroveň kardiorespirační a svalové vytrvalosti, které spolu s optimální úrovni BMI tvoří základní komponenty ZOZ (Stodden, Langendorfer, \& Roberton, 2009). Rozvoj hrubých pohybových dovedností během dětství pomocí nejpestřejších forem PA může představovat základ pozitivního trendu rozvoje TZ a pohybových návyků během dětství, dospívání a dospělosti (Stodden et al., 2008). Paralelní rozvoj hrubých pohybových dovedností a TZ u dětí a mládeže přispívá pozitivně k současnému stavu celkového zdraví a pohody („well-being“) (Rivilis et al., 2011). Děti mají možnost pomocí aktivního zapojení do pohybových her a jiných druhů PA získat motorickou zručnost, a proto mají potřebu učit se a zdokonalovat hrubé pohybové dovednosti pomocí široké nabídky existujících aktivních her (Logan, Robinson, Wilson, \& Lucas, 2012). Podle Hardyho et al. (2012) většina dětí dosáhne své optimální úrovně TZ během školní a mimoškolní pohybové aktivity, kde vykonávají různé pohyby, kterými jsou například běhaní, šplhaní, skákání nebo valení. Hlavním cílem předložené studie bylo zjištění vztahů mezi komponentami hrubých pohybových dovedností a TZ u dětí středního školního věku z olomouckého regionu. Dílčím cílem byla analýza intersexuálních rozdílů u sledovaných parametrů.

\section{METODIKA}

\section{Charakteristika souboru}

Výzkumný soubor tvořili žáci ze 4 vybraných základních škol v Olomouci, kteří byli vybráni na základě dostupnosti (Hendl, 2012). Výběr souboru byl zvolen záměrně, jelikož se děti středního školního věku nacházejí v důležitém stadiu motorického vývoje, který je vhodným senzitivním obdobím pro rozvoj určitých motorických schopností. Výzkumný soubor zahrnoval 100 jedinců ve věku 9-11 let, z čehož bylo 51 chlapců v průměrném věku 9,64 $( \pm 0,52)$ a 49 dívek v průměrném 
věku 9,14 $( \pm 0,64)$. Ředitelům vybraných škol, kteří souhlasili se spoluprací, byl detailně popsán průběh testování. Rodiče dětí byli prostřednictvím informovaného souhlasu ujištěni o nízkém zdravotním riziku testovacích metod, anonymitě při zpracovávání výsledků a dobrovolné účasti v testování. Testování proběhlo během prosince 2013 a března 2014 ve vyučovacích jednotkách tělesné výchovy.

\section{Charakteristika výzkumných metod}

Pro testování hrubých pohybových dovedností bylo použito druhé vydání testu s názvem Test of Gross Motor Development (TGMD-2) (Ulrich, 2000). Test obsahuje 12 položek rozdělených do dvou subtestů: (a) lokomočních a (b) manipulačních pohybových dovedností. Do lokomočních dovedností jsou zahrnuty běh, cval vpřed, skoky na jedné noze, přeskakování, skok snožmo a cval boční. Do manipulačních dovedností patří odpal míče obouruč, driblink, chycení míče, kop do míče, hod míčem vrchem a kutálení míče. Každá ze zmíněných dovedností obsahuje 3 až 5 hodnotících kritérií. Bodování jednotlivých kritérií se provádí na základě splnění ( 1 bod) či nesplnění ( 0 bodů) konkrétního kritéria. Každá dovednost se provádí a boduje dvakrát. Před samotným testováním se na základě praktického provedení administrátora provádí dva zkušební pokusy jednotlivých pohybových dovedností. Po sečtení bodů z obou subtestů vznikne tzv. hrubé skóre. Maximální počet bodů hrubého skóre je 96 (lokomoční dovedností 0 až 48 bodů a manipulační dovednosti 0 až 48 bodů). Hrubé skóre je převedeno na základě kalendářního věku a pohlaví na percentily a poté na standardní skóre. Součtem standardního skóre obou subtestů se vypočítá koeficient motorického rozvoje („Gross Motor Quotient“ - GMQ) (Ulrich, 2000). Pro předloženou studii byly použity zvlášt součty bodů hrubého skóre z lokomočních a manipulačních dovedností.

Tělesná zdatnost byla testována pomocí testové baterie FITNESSGRAM (Plowman \& Meredith, 2013). Hlavní složky testové baterie FITNESSGRAM se dělí do třech základních skupin: (a) kardiorespirační zdatnost, (b) svalová síla a vytrvalost a (c) flexibilita (Plowman \& Meredith, 2013). Pro zjištění kardiorespirační zdatnosti byl vybrán test Vytrvalostní 20metrový člunkový běh („The Progressive Aerobic Cardiovascular Endurance Run“ [PACER]). Cílem testu je vydržet běžet co nejdéle na vzdálenost $20 \mathrm{~m}$ tam a zpět podle zvukových intervalů z kompaktního disku (CD). Čas mezi zvukovými intervaly se každou minutu zkracuje, a tím se zkracuje čas na přeběhnutí 20metrové vzdálenosti. Trojité pípnutí na konci každé minuty oznamuje konec kola a další zvýšení rychlosti. Zaznamenává se počet přeběhů 20metrové vzdálenosti (Plowman \& Meredith, 2013).

Pro zjištění flexibility byl použit test Předklon v sedu pokrčmo jednonož. Testovaný jedinec v sedu pokrčí jednu dolní končetinu a druhou nataženou dolní končetinou se opírá chodidlem o měřicí box. Cílem testu je v předklonu nataženými pažemi a prsty dosáhnout nejdále na stupnici na povrchu měřicího boxu (Plowman \& Meredith, 2013).

Pro zjištění svalové síly a vytrvalosti byly vybrané dva testy (Plowman \& Meredith, 2013):

1) $90^{\circ}$ kliky: Cílem testu je provést co nejvyšší počet opakování (kliků) ve stanoveném tempu dle pokynů audionahrávky (jeden cyklus za tři sekundy). Výchozí polohou testu je vzpor ležmo. Koncová poloha je klik, přičemž předloktí a nadloktí svírají uhel od $90^{\circ}$. Zaznamenává se počet opakování.

2) Hrudní předklony v lehu pokrčmo: test se zahajuje $z$ lehu pokrčmo s chodidly na podložce a nataženými pažemi podél těla. Cílem testu je zvednutí trupu a hlavy silou břišních svalů a současně posunutí dlaní po podložce vpřed ve vymezeném rozsahu. Pohyb musí být prováděn ve stanoveném tempu (jeden cyklus za tři sekundy) podle pokynů audionahrávky. Zaznamenává se počet opakování. 


\section{Statistická analýza dat}

Deskriptivní statistika (procenta, průměr a směrodatná odchylka) byla použita pro zjištění charakteristik výzkumného souboru. Studentův t-test byl použit pro zjištování intersexuálního rozdílu u subtestů TZ a hrubých pohybových dovedností. Pearsonův koeficient byl použit pro zjištění vztahů mezi komponenty testů TGMD-2 a FITNESSGRAM. Hodnoty výsledných korelačních koeficientů byly věcně interpretovány podle Chrásky (2007): menší než $0,20=$ velmi slabá závislost, 0,20-0,39 = nízká závislost, 0,40-0,69 = střední závislost, 0,70-0,89 = vysoká závislost, větší než 0,90 = velmi vysoká závislost. Statistické zpracování výsledků bylo provedeno pomoci softwaru STATISTICA 13. Statistická významnost byla stanovena na hladině $\mathrm{p}<0,05$.

\section{VÝSLEDKY}

V tabulce 1 jsou představeny výsledky všech subtestů TZ a komponent hrubých pohybových dovedností u celkového souboru a souboru chlapců a dívek. Dále jsou představeny intersexuální rozdíly u daného souboru. Výsledky t-testu ukazují, že se v subtestech TZ Hrudní předklony v sedu pokrčmo $(\mathrm{t}=-1,01, \mathrm{p}=0,31)$ a lokomoční dovednosti $(\mathrm{t}=0,56, \mathrm{p}=0,57)$ neobjevily signifikantní intersexuální rozdíly. U všech ostatních subtestů byly nalezeny statisticky významné intersexuální rozdíly. Chlapci mají signifikantně vy̌šśí výsledky v subtestech PACER test $(\mathrm{t}=-4,49, \mathrm{p}<0,0001)$ a $90^{\circ}$ kliky $(\mathrm{t}=-3,91, \mathrm{p}<0,0001)$. Dívky mají signifikantně vyšší výsledky v subtestu Předklon $\mathrm{v}$ sedu pokrčmo jednonož $(\mathrm{t}=4,89, \mathrm{p}<0,0001)$. V rámci hrubých pohybových dovedností mají chlapci signifikantně vyšší výsledky v manipulačních dovednostech $(\mathrm{t}=-5,19, \mathrm{p}<0,0001)$ a celkovém počtu bodů u lokomočních a manipulačních dovedností $(\mathrm{t}=-3,84, \mathrm{p}<0,0001)$ (Tabulka 1$)$.

Tab. 1: Výsledky subtestů TZ a složek hrubých pohybových dovedností a hodnocení významnosti intersexuálních rozdílů.

\begin{tabular}{|l|c|c|c|}
\hline & Chlapci $(\mathbf{n}=\mathbf{5 1})$ & Dívky $(\mathbf{n}=\mathbf{4 9})$ & Celkem $(\mathbf{N}=\mathbf{1 0 0})$ \\
\hline PACER test (počet přeběhů) & $37,98( \pm 14,39)$ & $28,53( \pm 8,36)$ & $33,35( \pm 12,89)^{*}$ \\
\hline $90^{\circ}$ kliky (počet) & $7,68( \pm 5,74)$ & $4,18( \pm 4,69)$ & $5,94( \pm 5,04)^{*}$ \\
\hline $\begin{array}{l}\text { Hrudní předklony } \\
\text { v lehu pokrčmo (počet) }\end{array}$ & $36,53( \pm 21,68)$ & $32,81( \pm 21,01)$ & $33,64( \pm 20,63)$ \\
\hline $\begin{array}{l}\text { Předklon v sedu pokrčmo } \\
\text { jednonož (cm) }\end{array}$ & $20,73( \pm 6,25)$ & $26,06( \pm 6,65)$ & $23,59( \pm 6,38)^{*}$ \\
\hline Lokomoční dovednosti (body) & $46,39( \pm 2,88)$ & $46,62( \pm 1.80)$ & $46,56( \pm 2,65)$ \\
\hline Manipulační dovednosti (body) & $43,90( \pm 4,69)$ & $39,57( \pm 5,14)$ & $41,69( \pm 5,07)^{*}$ \\
\hline $\begin{array}{l}\text { Celkem manipulační } \\
\text { a lokomoční dovednosti (body) }\end{array}$ & $90,35( \pm 6,25)$ & $86,34( \pm 6,05)$ & $88,36( \pm 6,24)^{*}$ \\
\hline
\end{tabular}

Poznámka: PACER - vytrvalostní člunkový běh, * - statistická významnost p <0,05.

V tabulce 2 jsou představeny výsledky vztahové analýzy mezi hrubými pohybovými dovednostmi a TZ. Z uvedených hodnot u celkového souboru je patrná signifikantní pozitivní korelace mezi PACER testem a všemi komponenty hrubých pohybových dovedností. Nízká závislost se objevila mezi PACER testem a lokomočními dovednostmi $(r=0,29, p=0,003)$. Střední závislost je nalezena mezi PACER testem i manipulačními dovednostmi $(r=0,42, p<0,0001)$, respektive $v$ celkovém počtu bodů $\mathrm{z}$ lokomočních a manipulačních dovedností $(\mathrm{r}=0,46, \mathrm{p}<0,0001)$. U subtestů svalové síly a vytrvalosti jsou patrné signifikantní korelace mezi subtestem $90^{\circ}$ kliky a manipulační dovednosti $(\mathrm{r}=0,35, \mathrm{p}<0,0001)$ a celkovým počtem bodů $\mathrm{z}$ lokomočních a manipulačních dovedností $(\mathrm{r}=0,34, \mathrm{p}<0,0001)$. U subtestu Hrudní předklony v lehu pokrčmo je nalezena signifikantní 
pozitivní nízká korelace $\mathrm{s}$ lokomočními dovednostmi $(\mathrm{r}=0,21, \mathrm{p}=0,03)$ a celkovým počtem bodů $\mathrm{z}$ lokomočních a manipulačních dovedností $(\mathrm{r}=0,26, \mathrm{p}=0,008)$. Mezi subtestem Předklon v sedu pokrčmo jednonož nebyly nalezeny signifikantní korelace s komponentami hrubých pohybových dovedností u celkového souboru bez ohledu na pohlaví (Tabulka 2).

Tab. 2: Korelace mezi Hrubými pohybovými dovednostmi a subtesty TZ u celkového souboru

\begin{tabular}{|l|c|c|c|}
\hline & $\begin{array}{c}\text { Lokomoční } \\
\text { dovednosti }\end{array}$ & $\begin{array}{c}\text { Manipulační } \\
\text { dovednosti }\end{array}$ & $\begin{array}{c}\text { Celkem manipulační } \\
\text { a lokomoční dovednosti }\end{array}$ \\
\hline PACER & $0,29^{*}$ & $0,42^{*}$ & $0,46^{*}$ \\
\hline $90^{\circ}$ kliky & 0,16 & $0,35^{*}$ & $0,34^{*}$ \\
\hline $\begin{array}{l}\text { Hrudní předklony v lehu } \\
\text { pokrčmo }\end{array}$ & $0,21^{*}$ & 0,17 & $0,26^{*}$ \\
\hline $\begin{array}{l}\text { Předklon v sedu pokrčmo } \\
\text { jednonož }\end{array}$ & 0,01 & $-0,01$ & $-0,03$ \\
\hline
\end{tabular}

Poznámka: PACER - vytrvalostní člunkový běh, * - statistická významnost $\mathrm{p}<0,05$.

Tabulka 3 představuje výsledky korelačního koeficientu mezi sledovanými proměnami u souboru dívek. Nízká signifikantně pozitivní korelace byla nalezena mezi subtestem PACER a manipulačními dovednostmi $(\mathrm{r}=0,32, \mathrm{p}=0,02)$ a celkovým počtem bodů $\mathrm{z}$ lokomočních a manipulačních dovedností $(\mathrm{r}=0,29, \mathrm{p}=0,04)$. Mezi ostatními komponentami TZ a hrubými pohybovými dovednostmi nebyly nelezeny signifikantně významné vztahy (Tabulka 3).

Tab. 3: Korelace mezi Hrubými pohybovými dovednostmi a subtesty TZ u dívek

\begin{tabular}{|l|c|c|c|}
\hline & $\begin{array}{c}\text { Lokomoční } \\
\text { dovednosti }\end{array}$ & $\begin{array}{c}\text { Manipulační } \\
\text { dovednosti }\end{array}$ & $\begin{array}{c}\text { Celkem manipulační } \\
\text { a lokomoční dovednosti }\end{array}$ \\
\hline PACER & 0,09 & $0,32^{*}$ & $0,29^{*}$ \\
\hline $90^{\circ}$ kliky & 0,00 & 0,20 & 0,14 \\
\hline $\begin{array}{l}\text { Hrudní předklony v lehu } \\
\text { pokrčmo }\end{array}$ & 0,05 & $-0,01$ & 0,07 \\
\hline $\begin{array}{l}\text { Předklon v sedu pokrčmo } \\
\text { jednonož }\end{array}$ & $-0,02$ & 0,15 & 0,02 \\
\hline
\end{tabular}

Poznámka: PACER - vytrvalostní člunkový běh, * - statistická významnost $\mathrm{p}<0,05$.

V tabulce 4 jsou představeny korelační vztahy u souboru chlapců. Na rozdíl od souboru dívek je u chlapců patrná nízká až střední signifikantní korelace u většiny sledovaných proměn. PACER test prokazuje nízkou závislost s manipulačními dovednostmi $(r=0,34, p=0,01)$ a střední závislost $\mathrm{s}$ lokomočními dovednostmi $(\mathrm{r}=0,44, \mathrm{p}=0,001)$ a celkovým počtem bodů $\mathrm{z}$ lokomočních a manipulačních dovedností $(\mathrm{r}=0,47, \mathrm{p}<0,0001)$. Subtest $90^{\circ}$ kliky prokazuje nízkou až střední signifikantní závislost $\mathrm{s}$ komponentami hrubých pohybových dovedností. Nízká závislost se objevila u vztahu s lokomočními $(r=0,28, p=0,04)$ a manipulačními dovednostmi $(r=0,39, p=0,004)$. Střední závislost je patrná ve vztahu s celkovým počtem bodů z lokomočních a manipulačních dovedností $(r=0,43, p=0,001)$. Subtest Hrudní předklon v lehu pokrčmo prokázal podobně jako subtest $90^{\circ}$ kliky nízkou až střední signifikantní závislost s komponentami hrubých pohybových dovedností. S lokomočními $(r=0,31, p=0,02)$ a manipulačními dovednostmi $(r=0,33, p=0,01)$ je nalezena signifikantně nízká závislost, zatímco střední signifikantní závislost byla prokázána $\mathrm{s}$ celkovým počtem bodů $\mathrm{z}$ lokomočních a manipulačních dovedností $(\mathrm{r}=0,40, \mathrm{p}=0,003)$. Mezi 
subtestem Předklon v sedu pokrčmo jednonož a komponentami hrubých pohybových dovedností nebyly nalezeny signifikantně významné korelace (Tabulka 4).

Tab. 4: Korelace mezi Hrubými pohybovými dovednostmi a subtesty TZ u chlapců

\begin{tabular}{|l|c|c|c|}
\hline & $\begin{array}{c}\text { Lokomoční } \\
\text { dovednosti }\end{array}$ & $\begin{array}{c}\text { Manipulační } \\
\text { dovednosti }\end{array}$ & $\begin{array}{c}\text { Celkem manipulační } \\
\text { a lokomoční dovednosti }\end{array}$ \\
\hline PACER & $0,44^{*}$ & $0,34^{*}$ & $0,47^{*}$ \\
\hline $90^{\circ}$ kliky & $0,28^{*}$ & $0,39^{*}$ & $0,43^{*}$ \\
\hline $\begin{array}{l}\text { Hrudní předklony v lehu } \\
\text { pokrčmo }\end{array}$ & $0,31^{*}$ & $0,33^{*}$ & $0,40^{*}$ \\
\hline $\begin{array}{l}\text { Předklon v sedu pokrčmo } \\
\text { jednonož }\end{array}$ & $-0,02$ & 0,11 & 0,07 \\
\hline
\end{tabular}

Poznámka: PACER - vytrvalostní člunkový běh, * - statistická významnost $\mathrm{p}<0,05$.

\section{DISKUSE}

Hlavním cílem předložené studie bylo zjištění vztahů mezi složkami hrubých pohybových dovedností a TZ. Dílčím cílem byla analýza intersexuálních rozdílů u sledovaných parametrů. Výsledky představené studie potvrzují už existující poznatky z jiných studií, ve kterých chlapci mladšího školního věku dosahují vyšší výsledky ve většině subtestů TZ (Rubín, Suchomel, \& Kupr, 2012). V subtestech PACER test a $90^{\circ}$ kliky byl prokázán statisticky významný intersexuální rozdíl. Podobné výsledky se objevily ve studii Rubín et al. (2012). V subtestu svalové síly a vytrvalosti Hrudní předklony v lehu pokrčmo chlapci v průměru dosáhli vyšších výsledků, kde se podobně jako ve studii Erwin a Castelli (2008) a Rubín et al. (2012) neprojevily statisticky významné rozdíly. Naopak dívky prokázaly vyšší výsledky v subtestu flexibility - Předklon v sedu pokrčmo jednonož, kde se objevil signifikantní rozdíl. Potvrdilo se tvrzení, že dívky mají lepší flexibilitu, na což ukazují i výsledky ze studií Rubín et al. (2012) a Mayorga-Vega, Merino-Marban a GarcíaRomero (2015).

Výsledky z této studii ukazují na široký rozsah mezi dosaženými individuálními výsledky v subtestech TZ jak u chlapců, tak u dívek. V subtestu PACER se počet přeběhů pohyboval v rozmezí 7 až 63 přeběhů u chlapců a 9 až 53 u dívek. U subtestu Hrudní předklony v lehu pokrčmo se počet opakování pohyboval v rozmezí 2 až 75 opakování u chlapců a 5 až 75 u dívek. U subtestů $90^{\circ}$ kliky se počet opakování u chlapců pohyboval v rozmezí 0 až 26 a u dívek 0 až 19 . Podobné výsledky s poměrně velkými rozdíly v subtestech TZ z testové baterie FITNESSGRAM nalézáme ve výzkumu u 11letých dětí v Mad’arsku (Welk, Saint-Maurice, \& Csányi, 2015), a to především v subtestu $90^{\circ}$ kliky u souboru dívek. Domníváme se, že takovýto široký rozsah mezi individuálními výsledky je př́tomen $\mathrm{z}$ důvodu rozlišné míry zapojení děti do mimoškolních pohybových aktivit. Vzhledem k tomu, že PA pozitivně souvisí s úrovni TZ (Castelli, \& Valley, 2007; Dencker, Thorsson, Karlsson, Lindén, Svensson, \& Wollmer, 2006), dalo by se předpokládat, že zapojení do mimoškolních pohybových aktivit (aktivní transport, kroužky, sportovní trénink, účast na táborech) pozitivně ovlivňuje úroveň TZ, především kardiorespirační zdatnost (Telford, Telford, Cochrane, Cunningham, Olive, \& Davey, 2016; Zahner, Muehlbauer, Schmid, Meyer, Puder, \& Kriemler, 2009).

Výsledky z této studie potvrzují trendy ohledně intersexuálních rozdílů v komponentách hrubých pohybových dovedností, ve kterých chlapci dosahuji signifikantně vyššího skóre v manipulačních dovednostech (Burns, Brusseau, \& Hannon, 2016; Butterfield, Angell, \& Mason, 2012; Liong, Ridgers, \& Barnett, 2015; Okely et al., 2001; Slykerman, Ridgers, Stevenson, \& Barnett 2016) 
a celkového počtu bodů z lokomočních a manipulačních dovedností (Burns et al., 2016; Liong et al., 2015; Okely et al., 2001). Dívky naopak dosáhly vyššího skóre v lokomočních dovednostech, kde se podobně jako ve výzkumech Burns et al. (2016), Liong et al. (2015) a Slykerman et al. (2016) nevyskytly signifikantní rozdíly. Manipulační dovednosti, které byly testovány v této studii (odpal míče obouruč, driblink, chycení míče, kop do míče, hod míčem vrchem a kutálení míče), zahrnují dovednosti používané především ve sportovních hrách. Míčové sporty jsou více oblíbené u chlapců než u dívek a vzhledem $\mathrm{k}$ tomu, že jsou chlapci tohoto věku více pohybově aktivní (Šnoblová, Jakubec, Sigmund, \& Sigmundová, 2015), narůstá možnost rozvíjet a zdokonalovat tyto dovednosti (Okely et al, 2001). Některé lokomoční dovednosti testované testem TGMD-2 jsou většinou přítomné v tanečních a gymnastických aktivitách, do nichž se dívky tradičně začleňují více než chlapci. Navíc dívky začleněné do tanečních kroužků a klubů mají tendenci k nižší úrovni manipulačních dovedností (Barnett, Hinkley, Okely, \& Salmon, 2013).

Předložená studie uvádí nízké až střední signifikantně pozitivní vztahy u souboru chlapců mezi všemi komponentami hrubých pohybových dovedností a většinou subtestů TZ: PACER test, $90^{\circ}$ kliky, Hrudní předklony v sedu pokrčmo kromě subtestu Předklon v sedu pokrčmo jednonož. (Tabulka 4). Burns et al. (2016) ukazují na nízkou pozitivní závislost mezi PACER testem a lokomočními, manipulačními dovednostmi a celkovým počtem bodů z lokomočních a manipulačních dovedností. Titíž autoři dále uvádějí vztah mezi subtestem Hrudní předklony v sedu pokrčmo a všemi komponentami hrubých pohybových dovedností, kde se objevila pozitivně nízká korelace. Mezi subtestem $90^{\circ}$ kliky a lokomočními dovednostmi a celkovým počtem bodů z lokomočních a manipulačních dovedností se projevily také nízké signifikantně pozitivní korelační vztahy (Burns et al., 2016). Hardy et al. (2012) uvádějí silné vztahy mezí nízkou úrovni kardiorespirační zdatností a nízkou úrovní ovladatelnosti manipulačními dovednostmi u chlapců.

U souboru dívek je patrná nízká pozitivní korelace pouze mezi subtestem PACER test a manipulačními dovednostmi a celkovým počtem bodů z lokomočních a manipulačních dovedností. Naopak Burns et al. (2016) ve své studií uvádějí nízkou pozitivní korelaci mezi všemi komponentami hrubých pohybových dovedností a většinou subtestů TZ (PACER test, $90^{\circ}$ kliky). Subtest Hrudní předklony v sedu pokrčmo prokázal pozitivní korelace s lokomočními dovednostmi a celkovým počtem bodů z lokomočních a manipulačních dovedností (Burns et al., 2016). Hardy et al. (2012) u souboru dívek představují signifikantní korelace mezi nízkou úrovní kardiorespirační zdatností a nízkou úrovní ovladatelnosti lokomočními dovednostmi.

U celkového souboru dětí bez ohledu na intersexuální rozdíly byla nalezena pozitivní stř̌ední signifikantní korelace mezi manipulačními dovednostmi a PACER testem (Tabulka 2), což poukazuje na již známé tvrzení, že jsou děti se stř̌ední až vysokou úrovni ovladatelnosti manipulačními pohybovými dovednostmi více začleněny do sportovních her a PA žádoucí manipulační dovednosti s míčem (Stoden et al., 2009). Takové aktivity časem mohou přinést rozvoj a narůst kardiorespirační zdatnosti (Burns et al., 2016). Podobné výsledky objevili ve své studii Stoden et al. (2014). Výsledky korelace mezi subtestem $90^{\circ}$ kliky ukazuje na nízkou signifikantně pozitivní závislost na manipulačních dovednostech. Ve své studií Castelli a Valley (2007) ukazují na podobně nízkou závislost mezi těmito sledovanými subtesty. Subtest Hrudní předklon v sedu pokrčmo v představené studii ukazuje na pozitivně nízkou korelaci se všemi komponentami hrubých pohybových dovedností. Castelli a Valley (2007) představují nízkou signifikantně pozitivní korelaci mezi manipulačními dovednostmi a tímto subtestem TZ. Ve své přehledové studii Cattuzzo et al. (2016) uvádějí, že jsou hrubé pohybové dovednosti a komponenty tělesné zdatnosti úzce spjaté přímo (pomocí nervosvalového mechanismu) i nepřímo (pomocí PA zaměřené na kardiorespirační zdatnost). Dlouhodobá začleněnost do míčových sportů má pozitivní vliv na rozvoj síly a vytrvalosti ve svalech horních končetin a trupu. Faigenbaum et al. (2011) uvádějí, že švihové pohyby (házení, kopaní, skákaní a běhaní) dominující v mnohých sportech potřebují vysokou úroveň fyzického 
úsilí a neuromuskulární koordinace, která následně vede k nárůstu a rozvoji ZOZ a hrubých pohybových dovedností. Vztah subtestu flexibility se všemi komponentami hrubých pohybových dovedností neprokázal žádnou signifikantní závislost (Tabulka 2). Výsledky jiných studií přináší podobné výsledky (Castelli \& Valley, 2007; Hands, 2008). Stoden et al. (2009) uvádějí negativně nízkou korelační závislost mezi subtestem Předklon v sedu pokrčmo jednonož a manipulačními dovednosti. Hands (2008) ukazuje na problematiku flexibility propojenou s hrubými pohybovými dovednostmi. Zvýšená flexibilita snižuje stabilitu kolem kloubů, což vede ke snížené kontrole i kvalitě při provádění hrubých pohybových dovedností. Naopak snížená flexibilita omezuje rozsah pohybu kloubů a následně vede k omezení celkového pohybu těla. Výsledky z předložené studie ukazují, že hrubé pohybové dovednosti, a především manipulační dovednosti pozitivně korelují s komponentami TZ. Manipulační dovednosti a určité komponenty TZ nejsou na sobě závislé a oba tyto faktory jsou velmi důležité pro optimální tělesný vývoj dětí. Tyto nálezy korespondují s jinými výzkumy prováděnými s rozlišným souborem a instrumenty pro zjištění úrovně hrubých pohybových dovedností a TZ (Hands, 2008; Stoden et al., 2008).

\section{ZÁVĚRY}

Úroveň hrubých pohybových dovedností a tělesné zdatnosti u dětí středního školního věku přináší významné intersexuální rozdíly. Vztah hrubých pohybových dovedností a tělesné zdatnosti u dětí středního školního věku je velice komplexní. Propojení a závislost těchto komponent mezi sebou a zejména jejich vztahy s pohybovou aktivitou představují moderní prístup k řešení problematiky aktivního životního stylu. Vzhledem $\mathrm{k}$ tomu, že soubory chlapců a dívek společně mají prokázanou signifikantní střední závislost především mezi kardiorespirační zdatností a manipulačními dovednostmi, doporučujeme, aby se v hodinách tělesné výchovy dával větší důraz na učení se a rozvoj manipulačních dovedností u dětí středního, respektive mladšího školního věku. Rozvoj těchto dovedností má pozitivní vliv na celkový zdravotní status a zvlášṫ na kardiorespirační zdatnost člověka a může být základem pro kladný vztah k pohybové aktivitě v dospělosti.

\section{Literatura}

Barnett, L., Hinkley, T., Okely, A. D., \& Salmon, J. (2013). Child, family and environmental correlates of children's motor skill proficiency. Journal of Science and Medicine in Sport, 16 (4), 332-336.

Bunc, V. (2008). Aktivní životní styl dětí a mládeže jako determinant jejich zdatnosti a tělesného složení. Studia Kinanthropologica, 9(1), 19-23.

Burns, R., Brusseau, T., \& Hannon, J. (2016). Multivariate associations among health-related fitness, physical activity, and TGMD-3 test items in disadvantaged children from low-income families. Perceptual and Motor Skills, 0(0), 1-19.

Butterfield, S. A., Angell, R. M., \& Mason, C. A. (2012). Age and sex differences in object control skills by children ages 5 to 14. Perceptual and Motor Skills, 114(1), 261-274.

Castelli, D. M., \& Valley, J. A. (2007). Chapter 3: The relationship of physical fitness and motor competence to physical activity. Journal of Teaching Physical Education, 26(4), 358-374.

Cattuzzo, M. T., dos Santos Henrique, R., Ré, A. H. N., de Oliveira, I. S., Melo, B. M., de Sousa Moura, M., ... \& Stodden, D. (2016). Motor competence and health related physical fitness in youth: A systematic review. Journal of Science and Medicine in Sport, 19(1), 123-129.

Dencker, M., Thorsson, O., Karlsson, M., Lindén, C., Svensson, J., Wollmer, P. (2006). Daily physical activity and its relation to aerobic fitness in children aged 8-11 years. European Journal of Applied Physiology, 96(5), 587-592.

Erwin, H. E., \& Castelli, D. M. (2008). National physical education standards: A summary of student performance and its correlates. Research Quarterly for Exercise and Sport, 79(4), 495-505.

Faigenbaum, A. D., Farrell, A., Fabiano, M., Radler, T., Naclerio, F., ... \& Myer, G. D. (2011). Effects of integrative neuromuscular training on fitness performance in children. Pediatric Exercise Science, 23(4), 573-584.

Hands, B. P. (2008). Changes in motor skill and fitness measures among children with high and low motor competence: A five-year longitudinal study. Journal of Science and Medicine in Sport, 11(2), 155-162. 
Hardy, L. L., Reinten-Reynolds, T., Espinel, P., Zask, A., \& Okely, A. D. (2012). Prevalence and correlates of low fundamental movement skill competency in children. Pediatrics, 130(2), 390-398.

Hendl, J. (2012). Přehled statistických metod. Analýza a metaanalýza dat. 4. vyd. Praha: Portál.

Chráska, M. (2007). Metody pedagogického výzkumu. Základy kvantitativního výzkumu. 1. vyd. Praha: Grada Publishing.

Kalaja, S., Jaakkola, T., Liukkonen, J., \& Watt, A. (2010). Fundamental movement skills and motivational factors influencing engagement in physical activity. Perceptual and Motor Skills, 111(1), 115-128.

Liong, G. H., Ridgers, N. D., \& Barnett, L. M. (2015). Associations between skill perceptions and young children's actual fundamental movement skills. Perceptual and Motor Skills, 120(2), 591-603.

Logan, S. W., Robinson, L. E., Wilson, A. E., \& Lucas, W. A. (2012). Getting the fundamentals of movement: a meta-analysis of the effectiveness of motor skill interventions in children. Child: Care, Health and Development, 38(3), 305-315.

Lubans, D. R., Morgan, P. J., Cliff, D. P., Barnett, L. M., \& Okely, A. D. (2010). Fundamental movement skills in children and adolescents: Review of associated health benefits. Sports Medicine, 40(12), 1019-1035.

Mayorga-Vega, D., Merino-Marban, R., \& García-Romero, J. C. (2015). Validity of sit-and-reach with plantar flexion test in children aged 10-12 years. Revista Internacional de Medicina y Ciencias de la Actividad Física y el Deporte, 15(59), $577-591$.

Měkota, K., \& Cuberek, R. (2007). Pohybové dovedností - činnosti - výkony. Olomouc, Česká republika: Univerzita Palackého.

Molnár, D., \& Livingstone, B. (2000). Physical activity in relation to overweight and obesity in children and adolescents. European Journal of Pediatrics, 159(1), S45-S55.

Morrow, J. R., Tucker, J. S., Jackson, A. W., Martin, S. B., Greenleaf, C. A., \& Petrie, T. A. (2013). Meeting physical activity guidelines and health-related fitness in youth. American Journal of Preventive Medicine, 44(5), 439-444.

Okely, A. D., Booth, M. L., \& Patterson, J. W. (2001). Relationship of physical activity to fundamental movement skills among adolescents. Medicine and Science in Sports and Exercise, 33(11), 1899-1904.

Ortega, F. B., Artero, E. G., Ruiz, J. R., España-Romero, V., Jiménez-Pavón, D., Vicente-Rodríguez, G., ... \& Ciarapica, D. (2011). Physical fitness levels among European adolescents: The HELENA study. British Journal of Sports Medicine, 45(1), 20-29.

Plowman, S. A., \& Meredith, M. D. (Eds.). (2013). Fitnessgram/Activitygram reference guide. $4^{\text {th }}$ ed. Dallas, TX: The Cooper Institute.

Rivilis, I., Hay, J., Cairney, J., Klentrou, P., Liu, J., \& Faught, B. E. (2011). Physical activity and fitness in children with developmental coordination disorder: A systematic review. Research in Developmental Disabilities, 32(3), 894-910.

Rubín, L., Suchomel, A., \& Kupr, J. (2012). Vztah somatických parametrů a motorické výkonnosti u 10-12letých jedinců. Česká kinantropologie, 16(2), 106-118.

Slykerman, S., Ridgers, N. D., Stevenson, C., \& Barnett, L. M. (2016). How important is young children's actual and perceived movement skill competence to their physical activity? Journal of Science and Medicine in Sport, 19(6), 488-492.

Stodden, D. F., Goodway, J. D., Langendorfer, S. J., Roberton, M. A., Rudisill, M. E., Garcia, C., \& Garcia, L. E. (2008). A developmental perspective on the role of motor skill competence in physical activity: An emergent relationship. Quest, 60(2), 290-306.

Stodden, D. F., Langendorfer, S. J., \& Roberton, M. A. (2009). The association between motor skill competence and physical fitness in young adults, Research Quarterly for Exercise and Sport, 80(2), 223-229.

Stodden, D. F., Gao, Z., Goodway, J. D., \& Langendorfer, S. J. (2014). Dynamic relationships between motor skill competence and health-related fitness in youth. Pediatric Exercise Science, 26(3), 231-241.

Schmidt, R. A., \& Lee, T. D. (2014). Motor learning and performance: From principles to applications. $5^{\text {th }}$ ed. Champaign, IL: Human Kinetics.

Šnoblová, R. Jakubec, L., Sigmund, E., \& Sigmundová, D. (2015). Srovnání školní a celodenní pohybové aktivity 9-10letých děvčat a chlapců. Tělesná kultura, 38(1), 92-106.

Telford, R. M., Telford, R. D., Cochrane, T., Cunningham, R. B., Olive, L. S., \& Davey, R. (2016). The influence of sport club participation on physical activity, fitness and body fat during Childhood and adolescence: The LOOK Longitudinal Study. Journal of Science and Medicine in Sport, 19(5), 400-406.

Ulrich, D. A. (2000). The Test of Gross Motor Development. $2^{\text {nd }}$ ed. Austin, TX: PRO-ED.

Williams, H. G., Pfeiffer, K. A., O'Neill, J. R., Dowda, M., Mclver, K. L., Brown, W. H. \& Pate, R. R. (2008). Motor skill performance and physical activity in preschool children. Obesity, 16(6), 1421-1426.

Zahner, L., Muehlbauer, T., Schmid, M., Meyer, U., Puder, J. J., \& Kriemler, S. (2009). Association of sports club participation with fitness and fatness in children. Medicine and Science in Sports and Exercise, 41(2), 344-350. 